\title{
RANCANG BANGUN SISTEM INFORMASI SKRIPSI DARING BERBASIS WEB (STUDI KASUS JURUSAN TEKNIK INFORMATIKA, UNIVERSITAS PAPUA)
}

\section{Design of Web Based Online Thesis Information Systems (Case Study Of Informatics Engineering Departement, Papua University)}

\author{
Getreda Gabrilla Karubaba ${ }^{1}$, dan Kristia Yuliawan ${ }^{2}$ \\ 1,2Jurusan Teknik Informatika, Fakultas Teknik Universitas Papua \\ Jl. Gunung Salju Amban Manokwari \\ Email: 1k.yuliawan@unipa.ac.id
}

Received 12 / $11 / 2018$, Revised 15 / 11 / 2018, Accepted 22 / 11 / 2018

\begin{abstract}
The application made in this study is used in the scope of the University of Papua Informatics Engineering Department, based on information and procedures for making the final thesis task of the Informatics Engineering Department of the University of Papua, this application was made using the Waterfall system development model and developed with PHP programming language with a CodeIgniter framework and MySQL Database. This Online Thesis application consists of 3 users. The first user in this application are the Chair of the Study Program who acts as the Administrator, the second is Thesis Supervisor, and The third is Students of the Informatics Engineering Department at the University of Papua. Available menu options are Upload Proposal, List of Proposals, Thesis Title List, Message, New Message, Inbox, Control Card Menu, Student List, Lecturer List, and Profile. Information System that can facilitate the search for proposals, thesis titles and guidance processes carried out by the Informatics Engineering Department of the University of Papua.
\end{abstract}

keywords-Online Thesis, Department, PHP, MySql, Codeigneter

\section{Pendahuluan}

Di Jurusan Teknik Informatika Salah satu cara mahasiswa dalam mendapatkan rekomendasi judul skripsi harus adalah dengan mencari informasi judul skripsi yang sudah ada terutama skripsi yang membahas masalah yang serupa dengan masalah yang ingin diangkat oleh mahasiswa yang ingin mengajukan skripsi. Dalam prakteknya, aktivitas bimbingan skripsi dilakukan dengan diskusi, tanya jawab, dan pemberian masukan melalui tatap muka antar mahasiswa dan dosen pembimbing. Permasalahan yang menjadi kendala selama ini adalah Pengajuan proposal skripsi yang selama ini berjalan masih dilakukan sacara manual.

Dokumentasi judul skripsi yang sudah digunakan kurang tertata dengan baik secara administrasi, karena hanya ditulis di buku daftar skripsi sehingga mahasiswa harus membaca judul skripsi yang sudah digunakan satu persatu agar tidak menggunakan judul yang sama. Selain itu dalam proses bimbingan skripsi mahasiswa dan dosen pembimbing mengalami kesulitas dalam mengatur waktu bimbingan karena perbedaan jadwal kesibukan masing-masing individu. 
Untuk mengatasi permasalahan tersebut, perlu dibuat aplikasi sistem pendukung bimbingan skripsi, yang dapat membantu menyelesaikan permasalahan yang dihadapi dalam proses bimbingan skripsi di Jurusan Teknik Informatika Universitas Papua. Aplikasi ini diharapkan akan memberikan kemudahan baik bagi para mahasiswa maupun dosen pembimbing untuk melakukan bimbingan skripsi sehingga dapat meminimalisir kesulitan dalam proses pembuatan tugas akhir skripsi akibat perbedaan jadwal antara mahasiswa dan dosen pembimbing, karena proses bimbingan skripsi semua bisa dilakukan secara online.

\section{Landasan Teori}

\subsection{Sistem Informasi}

Sistem informasi adalah sekumpulan komponen yang saling berhubungan, mengumpulkan atau mendapatkan memproses, menyimpan, dan mendistribusikan informasi untuk menunjang pengambilan keputusan dan pengawasan dalam suatu organisasi. Sistem informasi adalah sistem di dalam suatu organisasi yang mempertemukan kebutuhan pengolahan transaksi harian, membantu dan mendukung kegiatan operasi, bersifat manajerial dari suatu organisasi dan membantu mempermudah penyediaan laporan yang diperlukan [1-2].

\subsection{Basis Data}

Basis data adalah kumpulan data yang saling berelasi, basisdata terdiri dari dua kata yaitu basis dan data. Basis kurang lebih dapat diartikan sebagai markas atau gudang tempat bersarang atau berkumpul, sedangkan data adalah representasi fakta dunia nyata yang mewakili suatu objek seperti manusia (Pegawai, Siswa, Pembeli, Pelanggan, Barang, dan Hewan) yang direkam dalam bentuk angka, huruf, simbol, teks, gambar, bunyi dan lain-lain[3].

\subsection{MySQL}

MySQL adalah salah satu perangkat lunak Database Management System (DBMS) yang sering digunakan saat ini, yang didistribusikan secara gratis di bawah lisensi (General Public License) (GPL). Sehingga setiap orang mudah untuk mendapatkan dan bebas untuk menggunakan MySQL[4].

\subsection{Database Management System (DBMS)}

Pengelolaan basis data secara spesifik tidak dilakukan oleh pemakai secara langsung, tetapi ditangani oleh sebuah perangkat lunak (sistem) yang khusus/spesifik. Perangkat inilah yang disebut DBMS yang menentukan bagaimana data diorganisasi, disimpan, diubah, dan diambil kembali. DBMS menerapkan mekanisme pengamanan data secara bersama, pemaksaan keakuratan/ konsistensi data dan sebagainya[3].

\subsection{Entity Relationship Diagram (ERD)}

ERD adalah suatu model jaringan yang menggunakan susunan data yang disimpan dalam sistem secara abstrak. Jadi, jelaslah bahwa ERD ini berbeda dengan DFD yang merupakan suatu model jaringan fungsi yang akan dilaksanakan oleh sistem, sedangkan ERD merupakan model jaringan data yang menekankan pada struktur-struktur dan relationship data [3]. 


\subsection{Data Flow Diagram (DFD)}

Perancangan aliran data adalah penggambaran dari aliran data yang masuk dan keluar dari sistem yang akan dibangun, aliran data dirancang menggunakan Data Flow Diagram (DFD). DFD terdiri dari empat simbol diantarannya entitas luar yang merupakan kesatuan diluar sistem yang dapat berupa orang, organisasi, atau sistem lainnya yang berada diluar lingkungan yang akan memberikan pengaruh terhadap sistem yang dibuat, arus data menunjukkan kemana data atau suatu sistem menuju. Arus data mengalir diantara proses, simpanan data, dan batas sistem proses yang merupakan kerja yang dilakukan oleh orang, mesin, komputer, atau sistem dari suatu data yang diinputkan untuk dihasilkan suatu data keluaran yang diinginkan, dan simpanan data yang merupakan tempat atau sarana yang digunakan untuk menyimpan data hasil proses yang dapat berupa file database, catatan manual dan lain sebagainya yang berfungsi sebagai penyimpanan[3].

\subsection{Bahasa Pemograman PHP (Personal Home Page)}

PHP adalah bahasa script yang dapat ditanamkan atau disisipkan ke dalam HTML. PHP banyak dipakai untuk memprogram situs web dinamis. PHP dapat digunakan untuk membangun sebuah CMS (Content Management System). PHP pertama kali dibuat oleh Rasmus Lerdrorf, yang bermula dari keinginan sederhana Lerdorf untuk mempunyai alat bantu dalam bermonitor pengunjung yang melihat situs web pribadinya. Inilah sebabnya pada awal pengembangan, PHP merupakan singkatan dari Personal Home Page tools, sebelum akhirnya menjadi Page Hypertext Preprocessor [5].

\subsection{Codelgniter}

CodeIgniter adalah sebuah framework PHP yang bersifat open source dan menggunakan metode MVC (Model, View, Controller). Codeigniter bersifat free alias tidak berbayar jika anda menggunakannya. Framework codeigniter di buat dengan tujuan sama seperti framework lainnya yaitu untuk memudahkan developer atau programmer dalam membangun sebuah aplikasi berbasis web tanpa harus membuatnya dari awal[5].

\subsection{Web Server}

Yang paling penting dalam instalasi CodeIgniter yaitu bahwa versi PHP minimal adalah versi 5.3 dan sudah di-install Mcrypt (salah satu ekstensi PHP), maka dari itu penulis memilih untuk menggunakan XAMPP sebagai Web Server. XAMPP merupakan aplikasi yang dibuat dan dikembangkan oleh Apache Friends. XAMPP merupakan singkatan dari X empat sistem operasi, A inisial dari Apache, M inisial dari MySQL, P inisial untuk PHP dan P yang terahkir untuk perl.

\subsection{MVC (Model-View-Controller)}

Pada dasarnya dalam konsep MVC ini, Model merupakan pengolah data dan berkomunikasi dengan database, view adalah tampilan yang ditampilkan ke user, sedangkan Controller merupakan pengolah request user dan mengembalikan request user dalam bentuk view. Jika dipetakan, alur kerja CodeIgniter akan tampak seperti gambar dibawah. Browser berinteraksi melalui controller. Controller-lah yang akan menerima dan membalas semua request dari browser. Untuk data maka controller akan meminta ke model dan untuk UI/template akan meminta ke view. 


\section{Metode Penelitian}

\subsection{Perangkat Keras dan Perangkat Lunak}

Adapun bahan dan alat yang peneliti gunakan untuk menyelasaikan penelitian ini dikelompokkan dalam dua bagian, yakni perangkat keras dan perangkat lunak.

\subsubsection{Perangkat Keras (Hardware).}

Perangkat keras yang digunakan dengan spesifikasi sebagai berikut:
a. Processor
: Intel Pentium (R) CPU 2,20 GHz
b. Memory RAM
: $2048 \mathrm{MB}$
c. Harddisk
: $320 \mathrm{~GB}$

\subsubsection{Perangkat Lunak (Software).}

Perangkat Lunak (Software) yang digunakan sebagai berikut:
a. Sistem Operasi Windows 7
b. XamppServer 3.2.2
c. PHP
d. Mozilla Firefox 41.0.1
e. MySQL
f. Framework CodeIgniter 3.0.6
g. Template admin Gentelella Alela

\subsection{Perangkat Keras dan Perangkat Lunak}

Prosedur penelitian yang digunakan untuk mengumpulkan data-data yang dibutuhkan oleh penulis adalah sebagai berikut:

\subsubsection{Studi Pustaka}

Mengumpulkan materi, data dan informasi dari narasumber, buku dan artikel yang dibutuhkan dalam pembuatan aplikasi ini. Pada tahapan ini penulis mengumpulkan materi, data dan informasi dari Buku Membangun Web dengan PHP dan MySQL, Buku Cara Belajar Framework Untuk Pemula. Penulis juga mengumpulkan informasi dari beberapa narasumber tentang Aplikasi Skripsi Online.

\subsubsection{Menformat Nama dan Afiliasi Penulis}

Dilakukan dengan wawancara kepada ketua jurusan dan seketaris jurusan teknik informatika universitas papua tentang standart operation procedure (SOP) Skripsi yang diterapkan.

\subsection{Metode Pengembangan Sistem}

Metode yang digunakan dalam pembuatan aplikasi ini yaitu adalah dengan menggunakan metode Systems Development Life Cycle (SDLC) dengan model perancangan waterfall. Metode Waterfall merupakan metode dalam mengerjakan pengembangan software dimana setiap fase harus 
dikerjakan dulu sebelum menuju ke fase yang berikutnya. Adapun metode waterfall dapat dilihat pada gambar berikut ini:

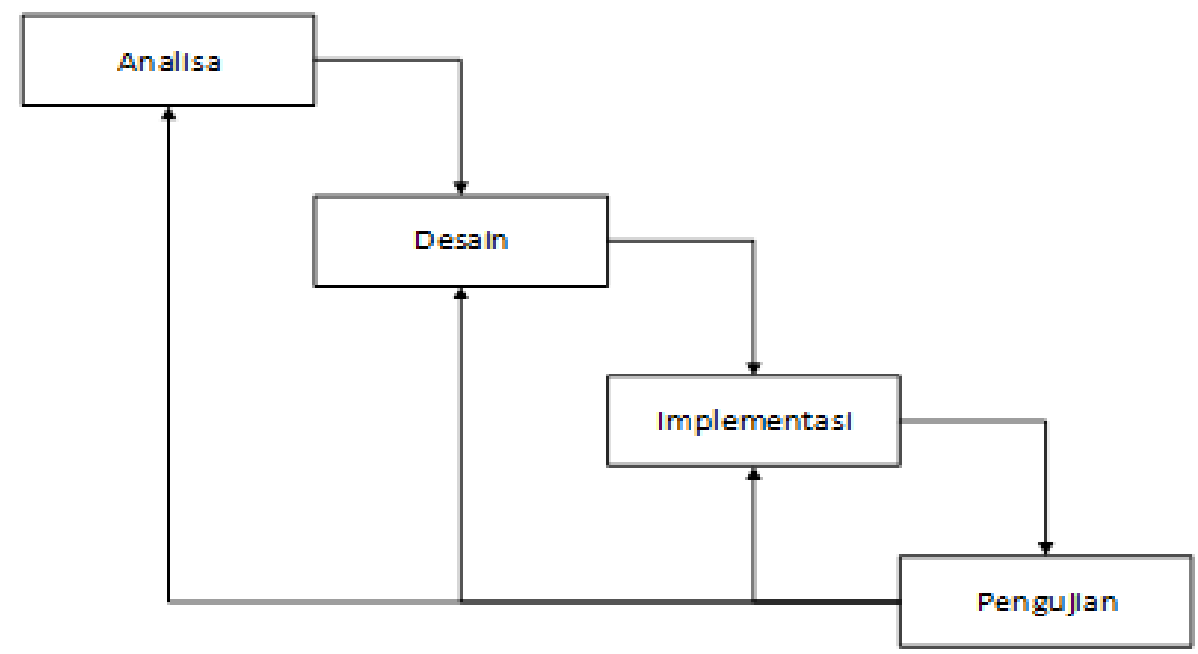

Gambar 1. Metode Pengembangan Sistem Model Waterfall

1. Analisa Sistem

Dalam tahapan ini, penulis melakukan analisa sistem yang akan dianlisa adalah Sistem pelaksanaan skripsi yang sedang berjalan di Jurusan Teknik Informatika Universitas Papua.

2. Desain Sistem

Pada tahap ini data yang telah dianalisa ke dibuat dalam bentuk desain yang lebih mudah untuk dimengerti. Desain sistem yang akan dibangun dimulai setelah tahap pembuatan DFD, ERD, Kamus Data dan Flowchart. Desain ini dapat didefinisikan sebagai penggambaran, perencanaan, dan pembuatan tampilan atau pengaturan dari beberapa elemen yang terpisah kedalam satu kesatuan yang utuh dan berfungsi.

\section{Implementasi Sistem}

Penulis mulai melakukan penulisan kode sistem menggunakan aplikasi Framework CodeIgniter dengan menggunkan PHP dan database Management System. Script yang ditulis antara lain pembuatan basisdata, sistem antara muka Login, setelah itu penulis menggunakan standar yang telah ada pada Framework CodeIgniter sesuai dengan spesifikasi yang telah diusulkan.

\section{Pengujian Sistem}

Pengujian terhadap program yang telah dibuat. Di tahap ini penulis melakukan pengujian dengan melakukan evaluasi terhadap sistem yang dibuat, apakah sistem yang didesain dapat berjalan sebagaimana mestinya, Pengujian Aplikasi Skripsi Online dengan metode Blackbox. 


\subsection{Metode Pengembangan Sistem}

Dalam proses pengembangan perangkat lunak, penulis mengunakan metode pengembangan system model Sekuensial Linear atau biasa disebut dengan metode pengembangan air terjun (metode waterfall), model pendekatan pengembangan system ini adalah model yang umum digunakan. Model ini mengusulkan sebuah pendekatan pengembangan secara sistematik dan sekunsial yang dimulai pada tingkat dan kemajuan sistem pada seluruh analisis, desain, implementasi dan pengujian dan penerapanya.

\section{Pembahasan}

\subsection{Analisa Sistem}

Aplikasi skripsi berbasis online ini dimulai dengan pengamatan terhadap sistem yang sudah dilaksanakan dunia nyata dimana mahasiswa masih melakukan bimbingan skripsi sacara tatap muka. Hasil pengamatan tersebut kemudian diterapkan ke dalam bentuk perangkat lunak yang mewakili dunia nyata tersebut.

\subsection{Desain Sistem}

\subsubsection{Diagram Konteks}

Diagram konteks merupakan alat untuk analisis struktur. Pendekatan struktur ini untuk menggambarkan sistem secara garis besar atau secara keseluruhan. Diagram konteks yang akan dibuat menghasilkan sumber informasi yang dibutuhkan dan tujuan yang akan dihasilkan. Diagram konteks dari sistem yang akan dibangun disajikan pada gambar dibawah ini.

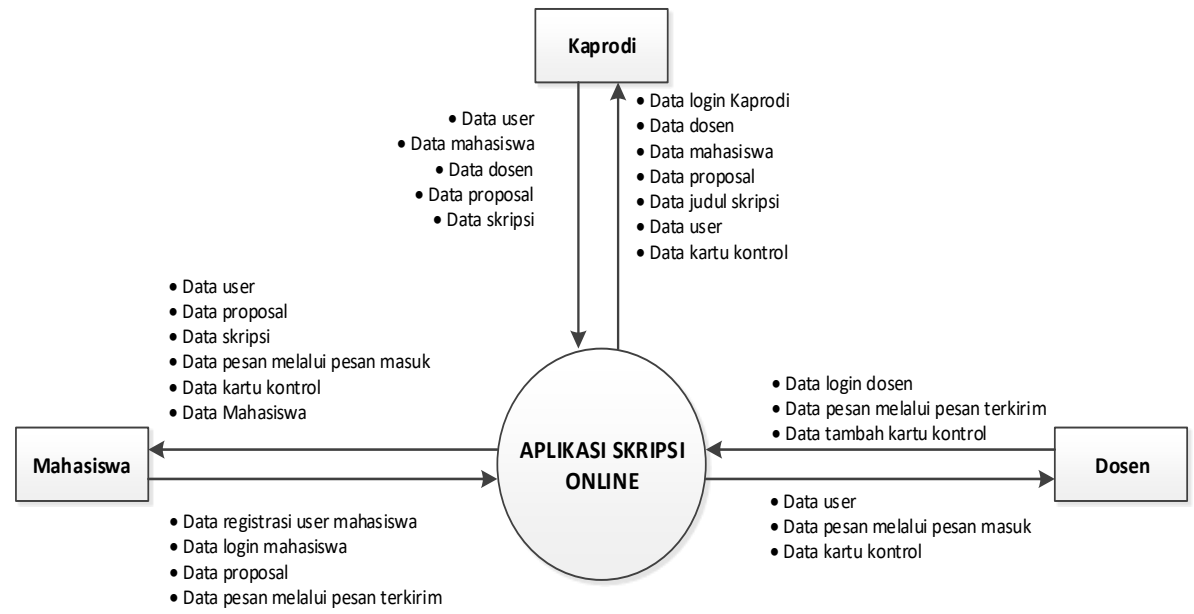

Gambar 2. Diagram Konteks

\subsubsection{DFD Level 1}

DFD Level 1 menjelaskan gambaran program dan jalannya proses yang terjadi dalam aplikasi skripsi online secara garis besar yang melibatkan entitas. Entitas yang terlibat dalam diagram konteks ada tiga, yaitu Kaprodi, Dosen, dan mahasiswa. Sedangkan proses yang terjadi dalam sistem terbagi menjadi delapan proses, yaitu proses login, pengolahan data user, pengolahan data mahasiswa, pengolahan data dosen, pengolahan data proposal, pengolahan data skripsi, pengolahan data pesan, 
dan pengolahan data menu kartu kaontrol. Diagram konteks sistem bimbingan skripsi online disajikan pada gambar dibawah ini.

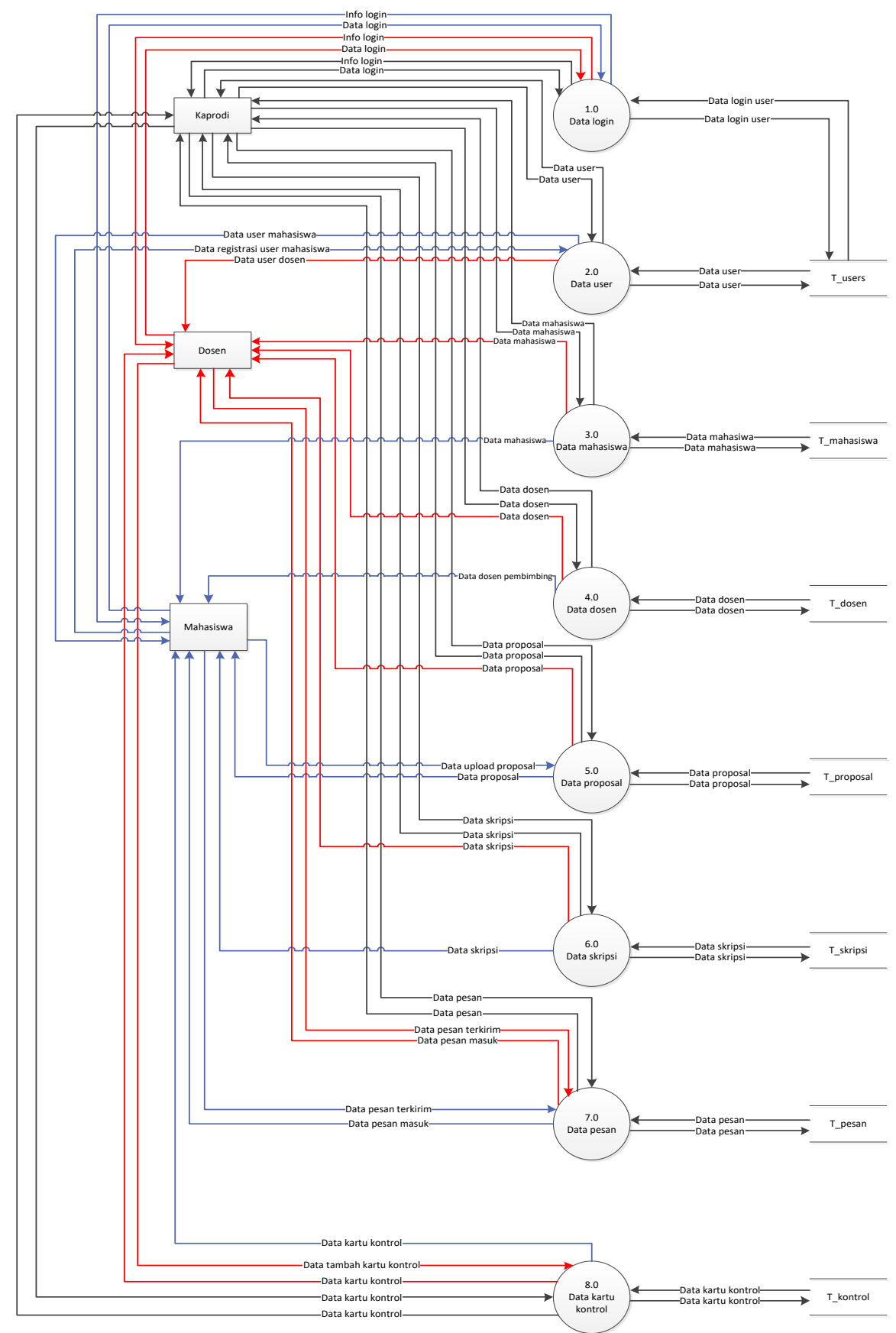

\section{Gambar 3. DFD Level 1}

\subsubsection{E-R Diagram}

Entity Relationship Diagram (ERD) merupakan suatu model untuk menjelaskan hubungan antar data dalam basis data yang berdasarkan objek-objek dasar data yang mempunyai hubungan antar relasi. Dibawah ini adalah Entity-Relationship Diagram (ERD) pada Aplikasi Skripsi online ini. 


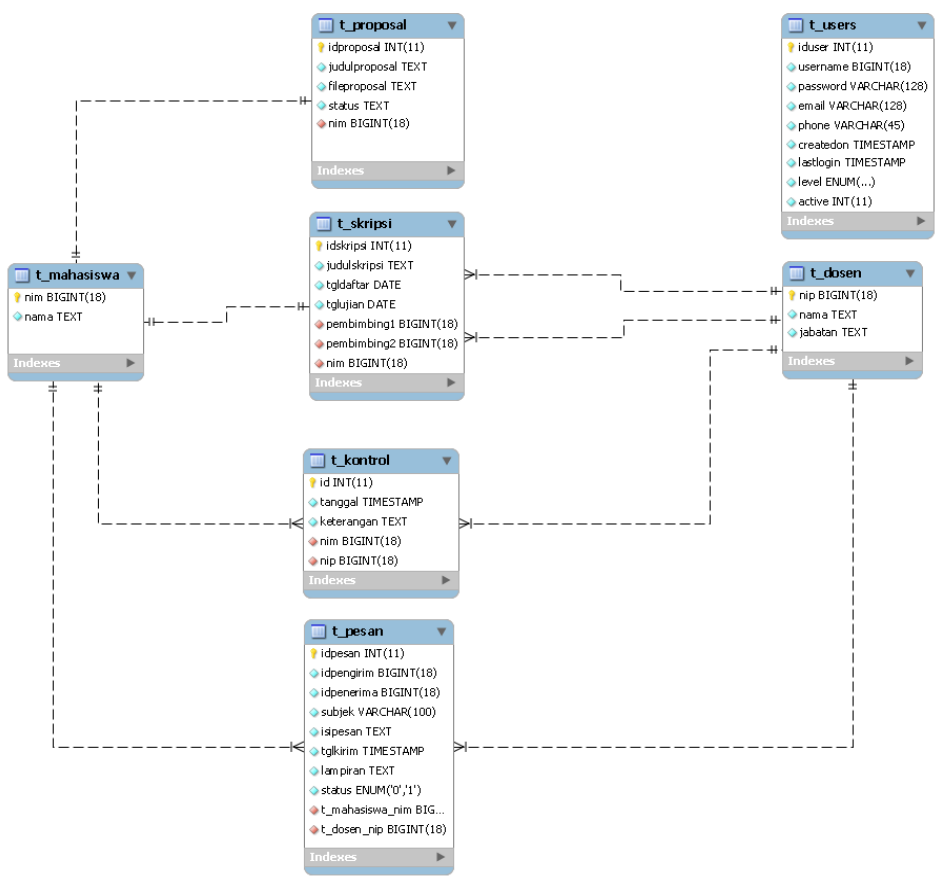

Gambar 4. Relasi ERD

\subsection{Implementasi Sistem}

\subsubsection{Halaman Login}

Halaman login adalah halaman pertama yang ditampilkan kepada pengguna yang belum login ketika mengakses Aplikasi skripsi online. Halaman login terdiri 2 field (kotak isian), yaitu Username dan password. Tampilan antar muka halaman login disajikan pada gambar berikut.

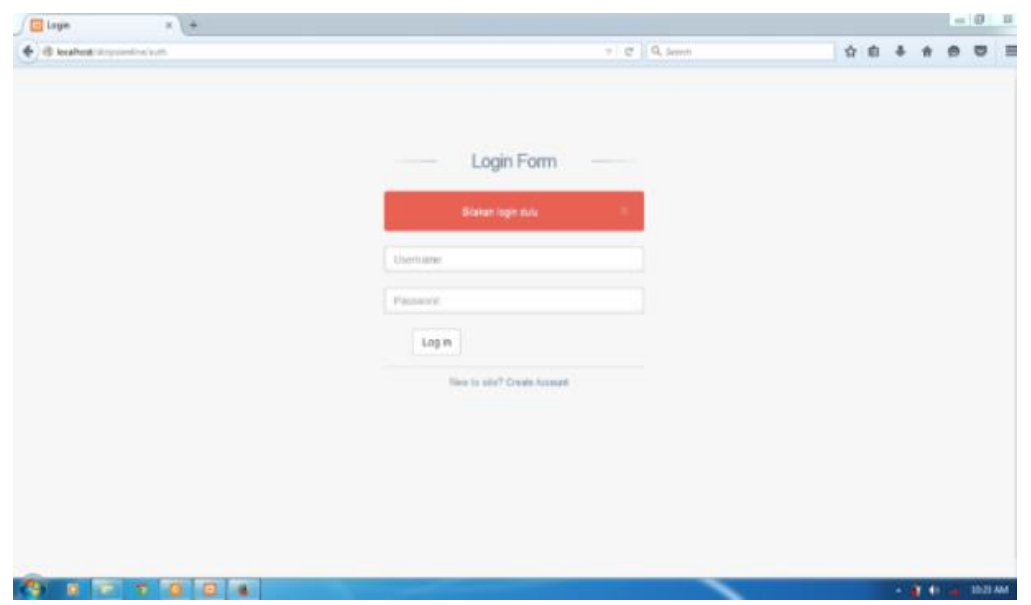

Gambar 5. Tampilan Antar Muka Halaman Login

\subsubsection{Tampilan Antar Muka Menu User ( Dosen dan Mahasiswa)}

Pengguna dengan hak akses Dosen dan mahasiswa dapat mengakses menu setelah login, yaitu menu Proposal Skripsi, Daftar Judul Skripsi, Pesan, Pesan Baru, Kotak Masuk, Kartu Konrtol, Data Dosen, Data Mahasiswa, dan Logout. Tampilan antar muka menu dan profil pengguna dengan hak akses Dosen disajikan pada gambar berikut. 


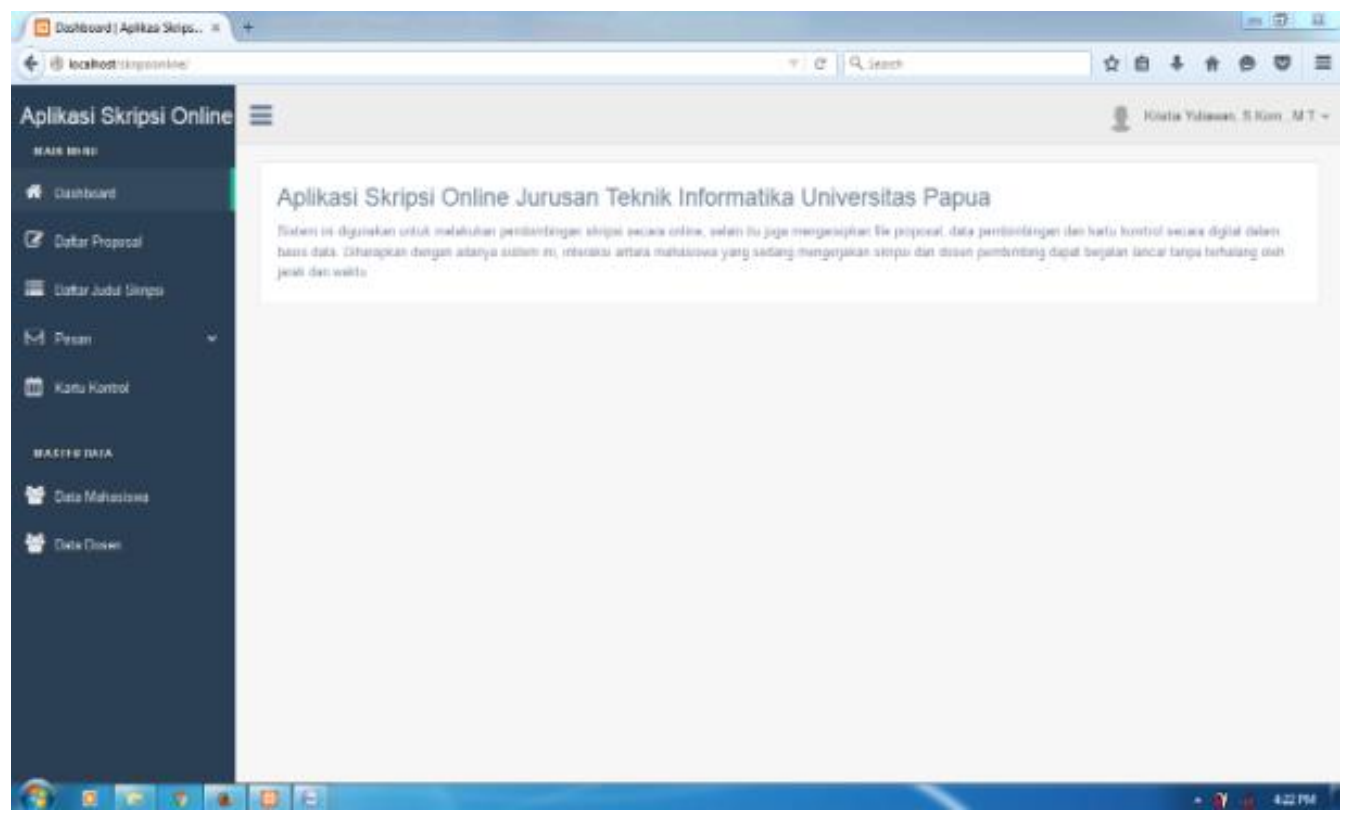

Gambar 6. Tampilan Antar Muka Menu dan Profil Pengguna Dosen

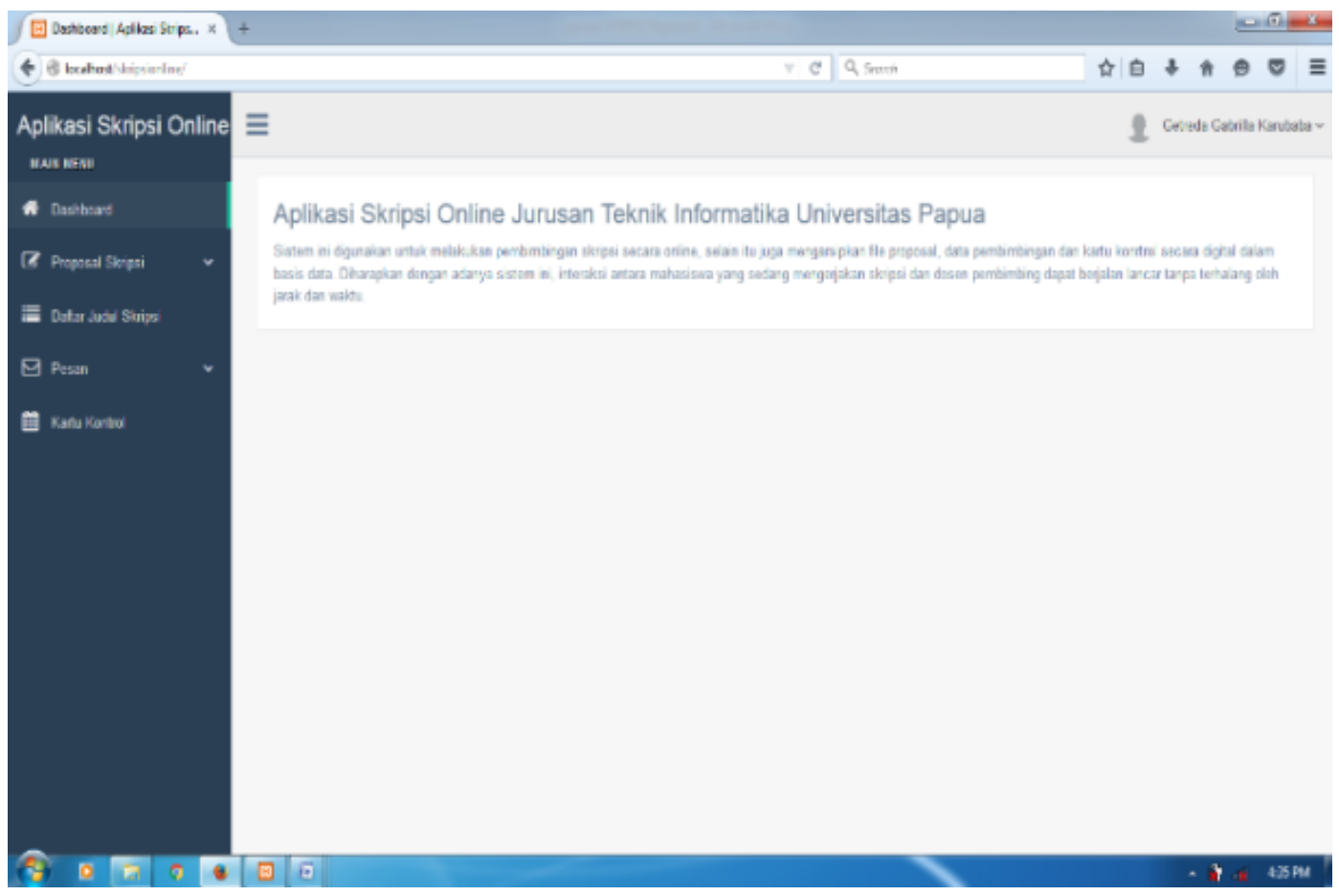

Gambar 7. Tampilan Antar Muka Menu dan Profil Pengguna Mahasiswa

\subsubsection{Tampilan Antar Muka Menu dan Profil Admin}

Pengguna dengan hak akses Admin dapat mengakses menu setelah login, yaitu menu Profil, Daftar Proposal, Daftar Judul Skripsi, Kartu Kontrol, Data Dosen, Data Mahasiswa, Data User dan Logout. Tampilan antar muka pengguna dengan hak akses Admin disajikan pada gambar berikut. 


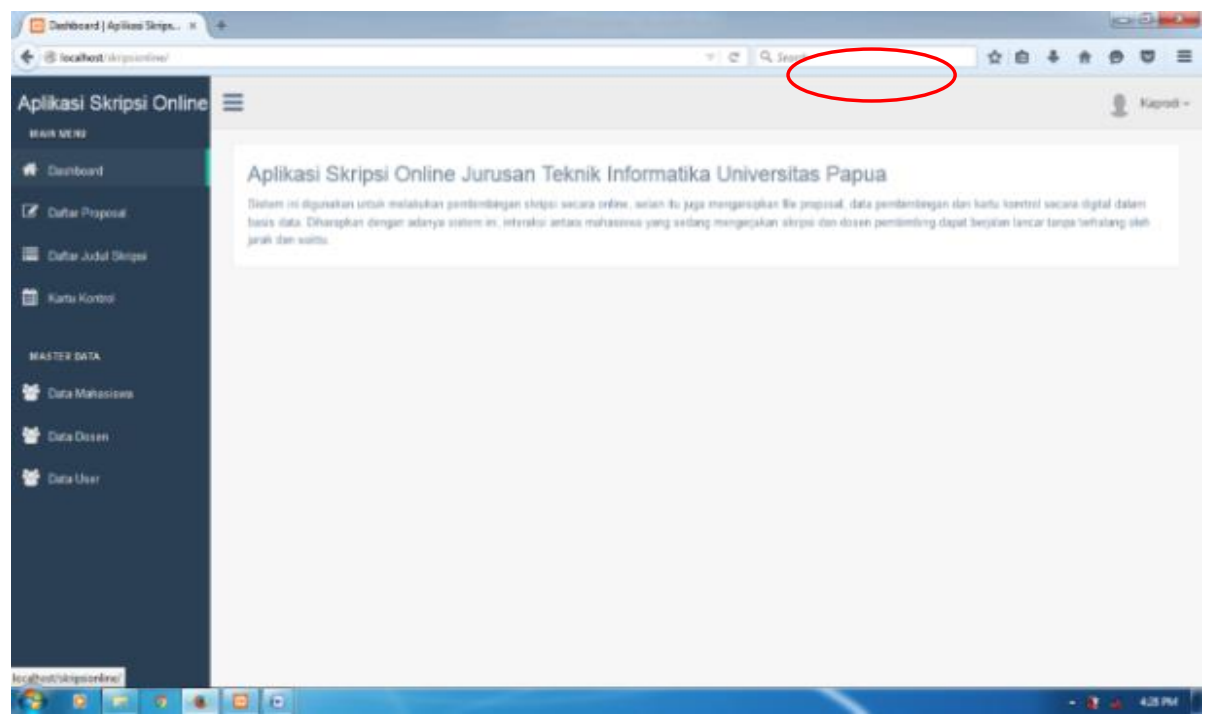

Gambar 8. Tampilan Antar Muka Menu dan Profil Admin

\subsection{Pengujian Sistem}

Untuk dapat mengatahui apakah aplikasi yang telah dibuat dapat berguna bagi user maka dibuatlah suatu kuesioner untuk dapat mengetahui tingkat kepuasan user terhadap aplikasi. Kuesioner akan disebarkan kepada tiga golongan masyarakat yaitu pegawai dinas infokom, Dosen, serta mahasiswa yang bertidak sebagai user.

Pertanyaan Kuesioner yang diajukan untuk dapat mengetahui tingkat kepuasan pengguna terhadap aplikasi adalah sebagai berikut:

1. Bagaimana pendapat anda tentang aplikasi peta berbasis android ini?

2. Menurut anda bagaimana informasi yang disediakan dalam aplikasi ini?

3. Apakah anda terbantu dengan adanya aplikasi peta berbasis android ini?

4. Bagaimana pendapat anda tentang keseluruhan fungsi aplikasi ini?

5. Apakah ada fitur yang membingungkan pada aplikasi ini?

Dari pertanyaan tersebut didapatkan hasil kuisoner dapat dilihat pada tabel sebagai berikut:

Tabel 1. Hasil Kuisoner Paritisipan

\begin{tabular}{|c|c|c|c|c|c|}
\hline \multirow{2}{*}{ No } & \multicolumn{4}{|c|}{ Pilihan Jawaban } & \multirow{2}{*}{$\begin{array}{c}\text { Total } \\
\text { Partisipan }\end{array}$} \\
\cline { 2 - 5 } & Sangat bagus & Bagus & $\begin{array}{c}\text { Kurang } \\
\text { bagus }\end{array}$ & Tidak bagus & 30 \\
\hline 1 & $80 \%$ & $20 \%$ & 0 & 0 & 30 \\
\hline 2 & $79 \%$ & $21 \%$ & 0 & 0 & 30 \\
\hline 3 & $53 \%$ & $47 \%$ & 0 & 0 & 30 \\
\hline 4 & $31 \%$ & $49 \%$ & $20 \%$ & 0 & 30 \\
\hline 5 & $80 \%$ & $20 \%$ & 0 & 0 & \\
\hline
\end{tabular}




\section{Kesimpulan}

Dengan adanya aplikasi ini, dapat dihasilkan kesimpulan bawa dari proses analisis, perancangan, pengujian dan implementasi yang dilakukan kepada Aplikasi Skripsi Online ini dapat memudahkan dosen dan mahasiswa untuk melakukan proses bimbingan tanpa harus bertatap muka secara langsung sehingga dapat meningkatkan efektifitas pembimbingan karena bisa dilakukan melalui media internet. Dari administrasi berdasarkan fitur-fitur sistem yang telah dibuat, Aplikasi Skripsi Online dapat membantu proses dalam dokumentasi data skripsi, pencarian judul skripsi, pengajuan proposal pengecekan daftar bimbingan, pengiriman pesan dan yang lainnya sehingga pengelolaan administrasi menjadi lebih efesien.

\section{DAFTAR REFERENSI}

[1] M. Agus Winarno, "Analisa dan Perancangan Sistem Informasi," PT Elex Media Komputindo, Jakarta, (2012).

[2] A. Kadir, Pengenalan sistem informasi. Andi, (2003).

[3] A. Kadir, Konsep \& Tuntunan Praktis Basis Data. Penerbit Andi, (1999).

[4] R. H. Sianipar, Membangun Web dengan PHP dan MySQL Untuk Pemula dan Programmer, vol. 1. Penerbit INFORMATIKA, (2015).

[5] M. S. A. E. Riyanto, "Commerce dengan PHP dan MySQL menggunakan CodeIgniter dan JQuery,” Yogyakarta: Andi, (2011). 